\title{
The Legal Framework and Women Status in the Hashemite Kingdom of Jordan
}

\author{
Saleh Al-Sharari ${ }^{1} \&$ Suheir AlKhatib ${ }^{2}$ \\ ${ }^{1}$ Department of Media and Strategic Studies, College of Art, Al-Hussein Bin Talal University, Ma'an, Jordan \\ ${ }^{2}$ Senior Manager, Bank of Montreal, Toronto, Canada \\ Correspondence: Saleh Al-Sharari, Dean of Scientific Research and Graduate Studies, Department of Media and \\ Strategic Studies, College of Art, Al-Hussein Bin Talal University, Amman, Jordan. E-mail: \\ Jssharari@gmail.com
}

Received: October 15, 2014 Accepted: November 18, 2014 Online Published: February 12, 2015

doi:10.5539/ass.v11n5p208

URL: http://dx.doi.org/10.5539/ass.v11n5p208

\begin{abstract}
This study aims to present the current status of women and the legislations that address women's related issues and rights in the Hashemite Kingdom of Jordan (referred to as Jordan). In addition, the study emphasises the importance of the international conventions concerned with human protection regardless of color, gender, religion, and race, which play an imperative role in diminishing the gender gap. Despite the fact that the study reveals that national legislation provide legal protection for women to a certain extent, further efforts are still required by Jordan to fulfill its international obligations. In practice, women still experience diminished political, economic and social role which is largely dominated by men. The study proposes a set of recommendations to enhance the protection of women's rights and their roles in Jordan such as further legal and regulatory reform and enforcement, conducting an awareness campaign in the country about women's rights under the Jordanian laws and international conventions, and implementing effective national programs aiming at increasing women's political, economic and parliamentary participation to reach regional and international averages.
\end{abstract}

Keywords: women, children, legal framework, women's rights, international convention, UNCRC, CEDAW

\section{Introduction}

Jordan is part of the Arab region and located in the Middle East of an area of 81,208sq. km. In 2013, the total population of the country was estimated to 6.53 million (excluding the number of refugees from neighboring countries) with an average growth rate of 2.2, and an average family size of 5.4. Women constitute about $48.5 \%$ of the total population. It is characterized by having a young population with $59 \%$ below the age of 25 and only 7.4\% above the age of 55 (Jordan Statistical Yearbook 2013, Department of statistics of Jordan, 2014).

During the last decade, Jordan has experienced tremendous influx of refugees from neighboring countries, mainly from Iraq and Syria due to the political instability of these countries. According to the United Nations Refugee Agency (UNCHR) records, it is estimated that about 642 thousand refugees are residing in Jordan as of January 2014; the majority of whom are from Syria since Iraqi refugees amounted to only about 30,000 as of March 2013(UNCHR website, 2014). Women and children constitute $80 \%$ of the refugees (Interagency Assessment, Peace and Security UN Women' 2013). Jordan has provided Syrian refugees with security and granted them access to services, such as health and education in host communities set up in the country.

There is no doubt that women of the world including Jordan have suffered tremendously throughout history and struggled to claim their rights as equal citizens, right to vote , equal employment opportunities and salaries, become parliament members and CEOs of Fortune 500 companies. The international community, along with the various women movements in the world, exerted remarkable efforts during the last century, to eliminate all forms of discrimination against women by passing international conventions and influencing national legislations and legal frameworks of the countries that are Party to these conventions, to guarantee women's rights and equality. In 1979, the first convention, Convention on the Elimination of all forms of Discrimination against Women - "CEDAW " was passed, and 1993 the Vienna Conference considered women's rights as an integral part of human rights that countries are responsible its advancement of and protection. The Jordanian government has demonstrated its commitment to international conventions by signing the CEDAW in December 1980, with a reservation, and ratifying it in July 1992 (United Nations Treaty Collection, 2014). 


\subsection{Research Objective}

The objective of this paper is to shed light on women's current status and the legal framework relevant to the protection of women's rights in Jordan. It aims to present and compare national legislation with some western ones and investigates Jordan's fulfillment of its obligations under international conventions to come out with some recommendations on how to improve women's status and protection in the country.

\subsection{Research Methodology}

This research is qualitative. Theoretical approach and analytical examination of Jordanian legislative framework of relevance to women's rights was followed in comparison with some other countries, mainly western, laws related to same subject. In addition, a review of relevant international conventions, sources and references was conducted.

\section{Women Status in Jordan}

Since the creation of the Hashemite Kingdom of Jordan, and the issuance of its first constitution in 1952, women have been considered equal to man under the Law. Taking a pioneer role in the subject of gender equality with regards to rights and duties, Article 6 thereof states the following: "Jordanians are equal before the law without discrimination in rights and duties on grounds of race, language or religion". In spite of this explicit text which enshrines the principle of equality among women and men, Jordanian women did not enjoy their full constitutional rights until the beginning of the fourth quarter of the last century due to cultural related issues.

Furthermore, equality among women and men Jordanian citizens without distinction was reaffirmed by the 1991 National Charter which was adopted in 2000 . The Charter contains three articles to guarantee equality before the law and equal opportunity in political participation, education, employment, business ownership, etc. For example: Chapter 5 paragraph 6 explicitly states that: "Jordanian men and women are equal under the law. There shall be no distinction between them in rights and obligations regardless of difference in race, language or religion..." And, Chapter one paragraph 8 states: "Women are men's partners and equals in contributing to the growth and development of Jordanian society. This requires an affirmation of women's constitutional and legal right to equality, guidance, training and employment as a means of enabling them to play their proper role in the growth and development of society" (UNCHR website, 2014).

Continuous efforts were exerted by Governments and various organizations to overcome these cultural obstacles to reach the current women status in the country. Today, Jordanian women have $12 \%$ representation in each of the Upper and Lower House of Parliament, constitute about $24 \%$ and the $36.5 \%$ of the workforce in the private and public sectors respectively and are Ministers, political activists, and main contributors to the economy and society in general.

\subsection{Political Status}

The Jordanian Society is characterized by being a patriotic society influenced by tribal culture, traditions and conservative religious beliefs. Consequently, women suffer from diminishing political and economic role even though they constitute almost half of the population. Despite the continuous support and efforts of King Abdullah II's and national initiatives to promote women's participation in politics, and introducing the quota system in 2003 parliamentary election and appointments of women in leading government positions, women still represent a minority of candidates in national elections and their representation in public office remains considerably modest and lower than that of men. Jordan ranks $115^{\text {th }}$ out of 153 countries in the representation of women in the lower house of national parliaments with $12 \%$ representation in both Lower, who representatives are elected by the people, and the Upper House of Parliament (the Senate) whom representatives are directly appointed by the King. Rwanda ranked first with an amazing representation of $63.8 \%$ in the Lower House and $38.5 \%$ in the Upper House surpassing Canada and the United States of America (USA) which ranked $55^{\text {th }}$ and $85^{\text {th }}$ respectively. In the USA, women comprise $18.3 \%$ and $20 \%$ of the House of Representatives and the Senate respectively, all of whom are elected by the people (Inter-parliamentary union (IPU) website, 2014). In order to increase the number of women in the elected Lower House of Parliament, Jordanian women have to overcome cultural and social barriers and see themselves as potential candidates and run for parliament. In addition, political parties should adopt a more gender-neutral policy and nominate more female candidates. When more women are nominated, more women are likely to be elected, especially if they are supported by their party. The best example is the Islamic Action Front Party female candidate that easily won the election because she was nominated and supported by her Party.

The first female Jordanian Minister was appointed in 1980 as the Minister of Social Affairs. The current cabinet of 2013 has only 3 women out of the 27 Ministers. This constitutes only $11 \%$ of the cabinet. This is much lower 
than the target of having 30 per cent women in positions at decision-making levels that was endorsed by the United Nations Economic and Social Council in 1995, and documented in the Beijing Declaration Platform for Action (Beijing Declaration, 1995). In comparison Canada has 44.4\% women Ministers in its current federal cabinet.

\subsection{Education}

Jordan is considered a pioneer in the region with regards to education, the level of literacy and number of public and private universities. Since the establishment of the Kingdom, gender equality has been guaranteed by the constitution, where females are treated as an equal person to man and have been provided with an equal right to education. Jordanian laws affirm fulfilment of this democratic right for all, regardless of gender, language or religion. Article 20 of Chapter 2 on the rights and duties of Jordanians of the constitution affirms that "Basic education shall be compulsory for Jordanians and free of charge in Government schools" (Jordan's Constitution, 2014). Furthermore, Jordan's Education Law No. 3 of 1994 reaffirms that basic education is compulsory. The Law mandates all Jordanian, irrespective of gender, to complete 10 years of basic education. In the school year 2012/2013, 1.4 million students attended primary schools (Grades 1-10) with a percentage of Girls of 49\%. And for the same year, about 106 thousand completed $12^{\text {th }}$ Grade (High School) of which 52\% are females (Jordan Ministry of Education (MOE) website, 2014).

Annually, about 268,650 students attend public and private universities in Jordan. $93 \%$ of them join undergraduate studies and only $7 \%$ post-graduate studies, of which $51.6 \%$ and $47.3 \%$ are women respectively (Jordan's Higher Education Annual Report for the year 2012/2013).

As for illiteracy rate, in 2012, adult female illiteracy rate (\% of $15+$ years of age) was $10 \%$, whereas it was only $3.5 \%$ for adult male (Ministry of Health website, 2014). The public and civic societies have multiple literacy programs to reduce the literacy rate in the country, many of which target women. The Ministry of Education established centers throughout the country to combat illiteracy. 5,530 women out of a total of 6,128 persons attended literacy programs which were offered by these centers in 2009 (MOE website, 2014).

\subsection{Economic Activities}

The World Bank report on Economic Participation, Agency and Access to Justice in Jordan of 2013 shows that despite the remarkable improvement in human development during the last few decades in Jordan, women's economic participation continues to be among the lowest in the world a "gender paradox". The 2013 WEF report on Gender Gap ranks Jordan $128^{\text {th }}$ among 136 countries in terms of women's economic participation way below any middle income countries, and below the Middle East and North America (MENA) region average of $25 \%$ even though this region is characterized by having world's lowest female labor force participation rates. In comparison to the western world, the USA ranks $6^{\text {th }}$ and Canada ranks $9^{\text {th }}$ for the same indicator (World Economic Forum (WEF) website, 2014).

In 2013 , the female labor force participation was less than $37 \%$, working mostly in the education sector $(43 \%$ of the total female labor force), followed by the health sector (13\%) and manufacturing (12\%). And, unemployment among women of the age $15+$ was almost double than the rate among men of the same age which was $22.6 \%$ and $10.6 \%$ respectively. Even though the Labor law does not discriminate between women and men with respect to pay, the average female monthly salary, in both the public and private sectors, was on the average $10 \%$ less than men. It is worth noting that for decision making professions; this discrepancy was much higher, for example female legislators, senior officials and managers are paid about 32\% less than men (Department of statistics of Jordan (DOS), 2013). The highest gender gap is evident in the agricultural sector where the percentage of agricultural holdings headed by women amounted to only 3\% in Jordan in 2010, whereas in Europe it ranged from $5.1 \%$ in the Netherlands to $47 \%$ in Latvia (Food and Agriculture Organization (FAO), 2014). Most studies indicate that social, political and cultural barriers hinder the active participation of Jordanian women in economic activities. As such, the government, in cooperation and collaboration with the private and non- profit sectors should enhance current efforts to diminish this gender gap.

\subsection{Sports}

Women and sports have always been a priority for Jordan. There is no law or regulations in Jordan that prohibits girls and women in participating in sports activities. They have equal opportunities as men to participate in sports and physical activities. Furthermore, the Jordanian Olympic Committee (JOC) Sports Federation Regulation No. 45 for the year 2013 article 5.4 mandates national sports federations "to encourage and support the participation of women". Additionally, the JOC created the Women and Sport committee to take a leading role in promoting sports in the country. 
Moreover, and to ensure women's participation in the administration and organization of the sports federations, article 20 of the regulation requires the federation's board membership to include at least one woman. The Secretary General of the JOC is Mrs. Lana AL Jaghbeer and 50\% of the staff at JOC is now women. In addition, talented female athletes have been winning medals internationally for many years for example Rana Qubbaj who won two gold medals at the World Jujitsu Championship in Dubai 2013 (JOC website, 2014)

\subsection{Institutional Framework}

In response to the World Conference that was held in Mexico in 1975, the Government of Jordan created the women directorate in the Ministry of Labor, which was later transferred to the Ministry of Social Development. The Directorate primary objective is to alleviate the gender gap in the country and increase women's economic participation. This is achieved by implementing various women capacity building programs, in cooperation with other government, non-profit organizations, regional and international institutions. In addition, the Ministry provides several social assistance services which include a social defense program that specifically target abused women and child, and a family and childhood protection program through which the government provides care facilities for orphans, abused children and children from broken families.

Other than the Ministry of Social Development, 17 other government institutions have gender related units that tackle women's issues that fall within their mandate, and are responsible for gender mainstreaming within their policies, strategies and plans. For example, the Gender Unit at the Ministry of Planning and International Cooperation, created under the Policies and Strategies Department in 2005, principal objective is to ensure appropriate institutionalizing of the gender perspective in the development projects and programs in the country.

In the voluntary field, Jordanian women have been pioneers and prominent figures in the Arab region with respect to gender equity and women empowerment. The first women, democratically elected organization was created in 1945. It is now known as the Jordanian Women's Union (JWU) which is comprised of individual members and women's non-profit organizations and associations. It is one of the oldest and most influential women's organizations in the country and the Arab region. Its major purpose is to improve the status of women in Jordan. In 1957, it had to discontinue its work due to political reasons in the country; Martial law was imposed and all non-government organizations were dissolved (Martial Law was implemented for some three decades). It re-emerged in the 70's but had to disband again. With the democratization of the country in 1990, JWU re-emerged and assumed its operations (JWU website, 2014).

In 1992, upon the recommendation of HRH Princess Basma Bint Talal, the Cabinet decided on the creation of the Jordanian National Commission for Women (JNCW) as a quasi-government agency tasked with improving the status of women in the country with regards to their political, social and economic participation in addition to achieving gender equity and social justice. In addition, there are a number of other non-profit organizations striving to enhance the status of Jordanian women, in particular rural women, such as the Jordan River Foundation, which is chaired by HM Queen Rania Al Abdullah, Noor Al-Hussein Foundation and Queen Alia Fund for Social Development.

\section{Jordanian Legal Framework on the Protection of Women}

In recent years, Jordan has undergone several positive regulatory and legislative reforms if enforced and implemented effectively, will improve the status of women and diminish the gender gap in the country. The following sections address Jordanian legislations' provisions of relevance to women.

\subsection{Constitution}

Since the creation of the Kingdom, women were considered as persons and equal before the law. The Jordanian Constitution, issued in 1952 and amended in 2011, lays down the basic principle that all Jordanians are equal without prejudice or inequity among them. Article 6 paragraph 1 thereof states the following: "Jordanians shall be equal before the law with no discrimination between them in rights and duties even if they differ in race, language or religion", and reaffirms this equity in work related and education sectors in paragraph 3 of the same article "The State shall ensure work and education within the limits of its possibilities, and shall ensure tranquility and equal opportunities to all Jordanians". Furthermore, Article 22 emphasizes the rights of Jordanians to public office, and that hiring should be based on capabilities and credentials: "1- Every Jordanian shall be entitled to hold public offices under the conditions prescribed in law or regulations; 2- Appointment to public offices, whether permanent or temporary, in the State and the departments attached thereto and the municipalities shall be on the basis of merits and qualifications".

Moreover, Article 23 of the constitution confirms the right of Jordanian citizens to work and point out explicitly the responsibility of the government to create employment opportunities by improving the national economy and 
protecting the labor force: "1-Work is the right of all citizens, and the State shall avail it to Jordanians by directing and improving the national economy; 2- The State shall protect labour and enact legislation".

In comparison, women in the USA were considered as an exclusive property to men till 1848. Man (He) had the general mandate and control over the household, marriage and divorce. Women protests against this injustice began initially in New York which was the trigger for many women's movements demanding rights for women and gender equity ever since. At the beginning, these movements only gained social sympathy without any legislative amendment. The American society perception regarding women did not change until 1920s, when some amendments were made to the American Constitution, Article 14. These amendments are known as "Paul" amendments and stated that: "Men and women shall have equal rights throughout the United States and every place subject to its jurisdiction". With these amendments, Paul intended to eradicate all sex discrimination and inequality in the American constitution, but it was not explicit enough with respect to gender equity, and what "equal rights" meant or included. Consequently, this resulted in discrepancies among American women's rights between "reformers" and "feminists". In addition, the1920's Amendment 19: gave women the right to vote by explicitly stating: "Prohibits any United States citizen from being denied the right to vote on the basis of sex" (Bartlett, 2000).

\subsection{Electoral Law}

Women were granted the right for voting and candidacy for the Lower House and Parliament and municipal and village councils in 1974 and 1982 respectively (CEDAW, 1997). It is worth noting that the parliament was suspended from 1968 till 1984, and the first parliamentary election that women voted and ran for was in 1989.10 women nominated themselves, but none of them was elected. In 1993, two women ran for parliamentary elections and only one of them succeeded in getting a seat, Ms. Tujan al-Faysal who became the first elected woman MP of Jordan.

To ensure the political participation of women, the Government took an affirmative action and amended the Electoral Law in 2003 to include a quota for women, similarly to the quota for minorities, with 6 seats out of the $110(5.45 \%)$. These seats will be held by women candidates attaining the highest percentage of all votes (females and males) in their respective electorates. As result, the 2003 elected Parliament had 6 women representatives, none of them would have secured their seats, if it wasn't for the quota, which confirmed that it was a necessary action to ensure women's parliamentary participation. In 2010, the Law was amended and the number of seats reserved for women was increased to 12 out of $120(10 \%)$. This percentage of representation was maintained in the 2013 amendments of the Law, where the number of seats was increased to 15 out of 150 . It is worth mentioning that the adoption of the quota system does not prevent the direct election of women to exceed this percentage. In the 2013 election, 3 women outside the quota were democratically elected by the person, which means that the percentage of Jordanian women MPs is $12 \%$. Unfortunately, women's percent parliamentary representation is still below the regional average of $25 \%$ and $18 \%$ short of the largely and globally recognized minimum benchmark threshold of $30 \%$.

In comparison, Rwanda, which is ranked number 1 in the world in women's representation in the Lower House (Chamber of Deputies) and Upper House (the Senate), took a bold move and adopted a strong candidate quota system to ensure women's participation in politics and decision making. Its constitution and Electoral Law explicitly adopts the $30 \%$ threshold.

The Constitution: "The State of Rwanda commits itself that women are granted at least 30 per cent of posts in decision making organs' (Constitution, Article 9 [4]). The 80 members of the Chamber of Deputies are elected as follows: 53 members elected by direct universal suffrage through a secret ballot using closed list proportional representation, of which at least 30\% must be seats reserved for women; 24 women (2 elected from each province and from the city of Kigali by an electoral college with a women-only ballot); 2 members elected by the National Youth Council; and 1 member elected by the Federation of the Associations of the Disabled (Constitution, Article 76)”.

"The State of Rwanda commits itself that women are granted at least 30 per cent of posts in decision making organs' (Constitution, Article 9 [4]). The total of 26 members of the Senate are either indirectly elected or appointed. Article 82 of the Constitution (2005) states that 'within the 26 members in the senate at least thirty per cent (30\%) should be women'. (Constitution, Article 82)".

And the Electoral Law states: "The election of the 24 women deputies from across the country's provinces is provided for in the following manner: 'Twenty four (24) female Deputies shall be elected by specific organs in accordance with national administrative entities. A Presidential Order shall determine a national administrative entity and the number of women Deputies to be elected at each entity. At each entity through which election has 
been conducted, candidates who obtain more votes shall be considered as elected' (Article 109 of Organic Law 03/2010/OL of 18 June 2010 governing presidential and legislative elections)" (IPU website, 2014).

In the 2013 election, Rwanda has achieved remarkable percentage of women's participation in both Houses exceeding the $30 \%$ benchmark. It reached about $64 \%$ (51 out of 80 seats) for the Lower House and about 39\% for the Upper House or Senate. This is a live proof of the adequacy of the quota system in promoting the active political participation of women in the country. Globally, 22 out of the 25 countries that attained $30 \%$ and more of women's parliamentary representation had applied some form of quota (Cool, 2013).

\subsection{Personal Status Law}

The Personal Status Temporary Law No. 82 of 2001, which is also known as "Family Law", organizes all matters related to the family including children. The Law is adapted from Islamic jurisprudence. The Law tackles marriage related matters including repudiation, alimony and divorce, wife adequate support, child custody and inheritance. The Law sets the eligibility for marriage which includes financial adeptness, as represented by the ability to pay a dowry and support, as well as religious eligibility; Muslim women are not allowed to get married to a non-Muslim under the Jordanian jurisdiction. The Law obliges the husband to pay his wife's living expenses and to provide help if she needs it. In the event of divorce, separation or annulment, the husband is responsible for bearing the expenses of raising the children and ensuring that they receive adequate education and health services. In the case, the woman is well-off and the father could not support the children, the cost incurred by the wife is considered debt payable by the husband when his financial condition improves. The Law acknowledges the right of women whom are divorced, widowed or married to a foreigner to obtain a separate family record book upon her request in accordance to article (58) which stated that "the right of Jordanian women divorced or widowed or married of foreign to have access to family book independently under a separate civil records if she desired" (Abu Ghazala, 2009)

In 2012, the Government of Jordan has introduced some positive major revisions to the Personal Status Law that affect family and personal rights such as: the creation of a fund to pay alimony and child support payments to women; added flexibility in marriage contracts to solidify women's rights in marriage and divorce; inclusion of justifications for woman to initiate divorce without the consent of a husband (iftidaa); extension of the custody period for mothers until the children reach the age of 15; in case of divorce father with guardianship of children cannot move them to a school away from the residence of the mother with custody; and notification requirement for men to take second wife, as polygamy is permissible under the Law (Islam permits man to take up to four wives).

Similarly, the Family law in the USA addresses family related matters and domestic relations. The law deals with marriage, annulment, divorce, child adoption child care and duties and responsibilities towards children, custody, property settlement in the event of separation or divorce, inheritance, and other family related matters. The intent of the Law is to protect families' interests, and deal with issues and problems that may arise between family members to ensure a stable family life (Hamilton, 2006). By the year 1980, amendments to legislations were established in many States regarding the distribution of properties between spouses either fairly or distributed between them equally in the event of separation or divorce (Barteltt, 1999).

It is worth mentioning that the USA permits non-Americans, living in the United States to apply their civic laws in their personal matters as long as they do not contradict federal laws. For example, Muslims in the United States can apply Islamic law in dealing with their families, but in case of conflict, the US laws will be applied in the US courts as a confirmation of the principles of sovereignty, even if one of the parties is non-American (Welchman, 2004).

\subsection{Nationality Law}

The Jordanian Nationality Law No. 6 of 1954 (amended in 1987) defines "Jordanians" as "any person who by virtue of this Law possesses Jordanian nationality". Article 3 stipulates who is deemed to be Jordanian which includes:

“(3) Any person whose father holds Jordanian nationality;

(4)Any person born in the Hashemite Kingdom of Jordan of a mother holding Jordanian nationality and of a father of unknown nationality or of a Stateless father or whose filiation is not established;

(5)Any person born in the Hashemite Kingdom of Jordan of unknown parents, as a foundling in the Kingdom shall be considered born in the Kingdom pending evidence to the contrary;" 
The Law is discriminatory against women by denying Jordanian wives and mothers to pass on their citizenship to their foreign spouses and children while it is automatic for men. This is reaffirmed in following Article 9 which states that "the children of Jordanian men shall be Jordanian wherever they are born", and Article 8 paragraph 1 says: "Subject to the approval of the Minister of Internal Affairs, a foreign woman who marries a Jordanian national may acquire Jordanian nationality if she so wishes by making a written statement to that effect". There are no synonymous articles for Jordanian woman's children and spouse. This contradicts the spirit of the Constitution to establish equality between Jordanian men and woman. Non-governmental organizations including the Jordanian Women's Unions and civic societies working in the field of human rights continues to call on the government to remove this discrimination and amend its nationality law, to be compliant with the CEDAW requirements, as per Article 9 paragraph 2, to establish equality among men and woman with respect to the nationality of their children; "States Parties shall grant women equal rights with men with respect to the nationality of their children". Jordan signed and ratified CEDAW with reservation to this article.

The Law recognizes the right of woman to retain her nationality, in the event she marries a foreigner (non-Jordanian), the event that her spouse acquired a nationality other than Jordanian, or if she acquires the nationality of a foreign State unless she renounces it in accordance with the provisions of this Law.

Most western nationality laws, grants the right to women to pass on their nationality to their children and spouses, especially in the event that a child is born in the country. For example, US citizenship is granted by either birth or naturalization. Any U.S. citizen, irrespective of sex, can apply for his/her spouse for permanent residency (Green card) in the USA, and once they satisfy the requirements of citizenship, s/he can apply for naturalization (US Department of Homeland Security, citizenship and immigration, 2014).

\subsection{Labor Law}

The Jordanian Labor law No 8 of 1996, and its amendments does not discriminate between genders with respect to remuneration, entitlement to social security and other benefits provided by the employer. The employers are expected to abide by this. The Law contains provisions specifically addressing working women matters. For example article 67 grants woman working in an establishment with 10 or more employees to take up to one year unpaid leave to take care of her family and her job is guaranteed upon return, unless she takes another paid job during her leave. Furthermore, and pursuant to article 68, a working woman or man can take an unpaid leave, for a period not exceeding two years, to accompany her/his spouse, in the event that $\mathrm{s} / \mathrm{he}$ takes a job in a Jordanian governorate different than the one s/he works in, or moves to work outside the country.

The Law provides the legal platform to impose some restrictions on the employment of women in certain professions and on night-time work hours. Article 69 states: "In accordance with a resolution of the Minister after consulting the competent official authorities, the following shall be specified: A. Industries and occupations in which employing women are prohibited; B. Times in which it is prohibited to make women work and the excluded cases".

The Law emphasises the wellbeing of working women. The provisions of the Jordanian labor law were modified to be consistent with women's rights and to accommodate for their commitment to motherhood. For-example Article 72 of the Jordanian Labor law No. 8 of 1996 states: "Employers with at least twenty married women workers in their employment shall provide an adequate facility under the care of a trained nurse for the women workers' children less than four years of age, if at least ten of them are in such an age group". In addition, it provides some protection against harassment where it gives the employee the right to leave the work with no notification while keeping his/her legal rights related to the end of service compensation and any other indemnities arising as a result of incurred damages if the employer or his representative assaulted him/her during work by beating or degradation.

Furthermore, the law grants every working woman 10 weeks of maternity leave to ensure that her health and the health of her child is protected during the pre and post natal periods with no restrictions imposed based on the duration of service with the employer. Pursuant to Article 70 of the Jordanian Labor Law No. 8 of 1996, "Working woman has the right to full paid maternity leave before childbirth and afterwards of total duration of 10 weeks in which such duration should not be less than 6 weeks after childbirth and it is prohibited to resume employment before the expiry of such duration". Moreover, Article 71 gives every working woman the right to take a paid leave to nurse (breast feed) her new born for a period of one year after the expiry of the maternity leave, provided that the leave time does not exceed one hour a day.

Jordan's Labor Law is consistent with the Arab Convention on Working Women No. 5 of 1976 which calls for the right of women to maternity leave as per Article 10 which states that: "working women have the right to obtain a fully paid leave before and after childbirth for a period of not less than ten weeks and such leave should 
not be less than six weeks after childbirth and it is prohibited to resume or start employment before the expiration of this period". But, it is below the international standard that was set by the International Labor Organization (ILO) of a minimum of 12 weeks with a recommendation of 14- weeks leave. In countries that provide paid leaves, the ILO states that the working women should be paid at least two-thirds of her previous insured earnings, with full health benefits (Abdel Mohsen, 2013).

Almost all countries in the world mandate the provision of paid maternity leave and health benefits by law. The USA is the only industrialized country, and among the few left in the World that does not mandate paid leave for mothers with newborns (ILO website, 2014). However, new parents are guaranteed their jobs after 12 weeks of leave as stipulated by the Family and Medical Leave Act of 1993 section 201 paragraph a.1.A which states: "ENTITLEMENT TO LEAVE.--Subject to section 103, an eligible employee shall be entitled to a total of 12 workweeks of leave during any 12-month period for one or more of the following: (A) Because of the birth of a son or daughter of the employee and in order to care for such son or daughter" (US Department of Labor website, 2014). However, the Act does not mandate that it has to be paid and is left to the employer's policies and benefits plans.

\subsection{Social Security Law and Pension}

Women in Jordan are entitled to social insurance and pension. Under the Temporary Social Security Law No. 7 of 2010, all organizations are obligated to register with the Social Security Corporation and provide its employees with social insurance benefits as mandated by the law without any gender bias. Women working from home can voluntarily join the Social Security Corporation. Recent amendments of the law were in favor of women, a widow can now inherit the full pension of a deceased husband and her share of an inherited pension from a son or daughter. Also, a female employee, equally to the male employee, can now pass her pension to her family. These rights were denied to women by earlier versions of the law. Furthermore, the new amended law requires maternity leave costs to be funded by a payroll tax on all workers, rather than financed by employers (World Bank Report No: ACS5158, 2013).

\subsection{Penal Law}

The Declaration on the Elimination of Violence against Women, which was issued by the UN in December 1993 , defines violence against women as "any act of gender-based violence that results in, or is likely to result in, physical, sexual or psychological harm or suffering to women, including threats of such acts, coercion or arbitrary deprivation of liberty, whether occurring in public or in private life". Article 2 of the declaration provides explicit examples of violence as follows:

"Violence against women shall be understood to encompass, but not be limited to, the following:

a. Physical, sexual and psychological violence occurring in the family, including battering, sexual abuse of female children in the household, dowry-related violence, marital rape, female genital mutilation and other traditional practices harmful to women, non-spousal violence and violence related to exploitation;

b. Physical, sexual and psychological violence occurring within the general community, including rape, sexual abuse, sexual harassment and intimidation at work, in educational institutions and elsewhere, trafficking in women and forced prostitution;

c. Physical, sexual and psychological violence perpetrated or condoned by the State, wherever it occurs."

The Fourth World Conference on Women that was held in Beijing, September 1995 reaffirms commitment to combat violence against women.

The Government of Jordan recognizes the seriousness of acts of violence against women and children. The amended Jordanian law No. 60 of 1960 (the law was amended several times; latest amendment: amendment no. 9 of 2014), is stringent in cases of rape (forced sexual intercourse), specifically for young women. For example, the penalty for raping a girl child under the age of 15 can be the death sentence (Death Penalty Worldwide website, 2014) and hard labor if she was at the age of 15 and under the age of 18 years.

Jordan, as an Islamic country forbids women trafficking and prostitution and both are punishable under the law. Furthermore, the law punishes any person who is involved in the set up and operation of a brothel, from ownership, management, leasing a location to be used as a brothel, etc. The law also punishes any person who allows a minor to live in a brothel whether a girl or a boy.

However, there is controversy about the effectiveness of the Law in prevention of violence acts against women and girls in the country. For example, "perpetrators are pardoned from punishment or legal prosecution if they marry their victims and stay with them five years. 99 cases were reported of suspected rape reported until the 
end of June of 2014, 95\% of the perpetrators managed to avoid punishment after they married their victims, thanks to article 308 of the Penal Code, judicial officials and experts said" (Azzeh, 2014). It is worth noting that there is a continuous national effort to amend the provisions that address "honor crimes" in the law specifically Articles 98 and 340 which remain in effect and state to date. Article 98 allows for a man to receive a reduction in penalty if he commits the crime in a state of fury, in addition, article 340 provide lay way to pardon the man who kills his wife or a female relative during the act committing adultery. The law fails to address incidents that when a wife catches her husband committing adultery, or engaged in unlawful acts. Although, Jordan claims that it follows Islamic laws (Shariah), both articles are in contradiction with what the Holy Quran says. The Holy Quran explicitly specifies the punishment for adultery, for single and married, and it does not discriminate based on gender. The same punishment applies to both men and women and does not give the right to any of them to commit murder because of fury, but rather requires evidences and witnesses to the act.

In Canada, women and men are equal under the law. Even though, Canada allows its diverse population to practice freely their faiths, in appropriate cultural practices, "honor crimes", spousal abuse, forced marriage mutilations, and gender based violence are considered crimes and perpetrators are severely punished under Canada's criminal laws.

Studies revealed that $40 \%$ to $70 \%$ of the murdered women in Australia, South Africa, Canada and the United States were killed by their spouses or partners. A study which was conducted in the United States showed that 78\% of young women between the ages of 15 to 18 years who were victims of intentional homicide were murdered by a person known or an intimate partner. According to the same study, this is the second cause of death among young women (Abu Ghazaleh, 2009).

The US judiciary system is stern with respect to the protection of women and eliminating violence against them. Everyone is equal before the law with no exceptions given to anyone even if they are celebrities or high-profile officials. The best demonstration of the effective implementation of the law is the issuance of a US court order in New York against the IMF Managing Director on May 16, 2011 who was arrested and charged by the Attorney General with six violations of the laws of the US which included sexual assault and attempted rape. This incident caused an embarrassment to the IMF and got huge attention from the American, European and French media for it was a scandal of renounced international public figure (Almadni, 2011).

With regards to abortion, it is considered a crime under the Jordanian law in the exception of specific cases such as if the continued pregnancy is harmful to the health of the women. Both the pregnant woman and the persons involved in the abortion are considered offenders and are subject to legal prosecution.

As of June 2013, 61 countries allow abortion without restrictions as to reason. The list includes one Arab country, Bahrain (Centre for Reproductive Rights website, 2014). The USA is 1 out of 7 countries that permit elective abortion 20 weeks of gestation (May, 2014)

\subsection{Public Health Law}

The Public Health Law No. 47 of 2008 guarantees the provision of necessary medical services to all Jordanian citizens. The Law addresses women related issues, maternity, childhood and family planning matters in specific. Pursuant to the Law, the Ministry of Health is required to establish maternal and child health centers throughout the country, and to offer medical and family planning services free of charge. In 2012, the total number of these centers was 444 spread among the twelve governorates (Jordan Ministry of Health (MOH) website, 2014). The centers provide prenatal, postnatal and child care which includes immunization which is compulsory under article 28 of this Law.

\section{Conclusion}

This paper looked at the present status of Jordanian women and the legal framework of relevance to women matters and compared it to other countries of the world. Increasing the women in parliament, both the Lower and the Upper House (Senate), from $12 \%$ to at least $30 \%$ is imperative to match the global benchmark and to ensure that half of the population of Jordan is well represented in Parliament.

Even though Jordan has exhibited gender equity in the health and education sectors, and has shown remarkable progress in improving women's life expectancy, literacy and enrollment in under and graduate studies, women's economic political and economic participation is still modest compared to other countries.

Recent legislative and regulatory reform, if enforced, will improve the protection of Jordanian women and will enhance her economic participation. However, effective implementation of these reforms is hindered by male dominant and tribal culture and conservative beliefs. 
The Jordanian government has demonstrated its commitment to international conventions on the protection of the rights of women by signing and ratifying the Convention on the Elimination of all forms of Discrimination against Women "CEDAW ", and amending its legislation to abide by the Convention's requirements. But, it maintained reservation to Article 9.2 which requires States Parties to grant women equal rights with men with respect to the nationality of their children.

In conclusion, Jordan needs to continue its legal reform to meet its international obligations and to exert more effort in enforcing these reforms in the country. Moreover, it is evident, that there is a need for implementing effective national women related programs to protect women and alleviate factors impeding women's progress and their political and economic participation.

\section{Recommendations}

- Adopting the parliamentary quota system has proven to be effective in Jordan and other countries in the world. As such, it is recommended to increase the quota for parliamentary women from $10 \%$ to $30 \%$ (the international benchmark), or at least to regional average of $25 \%$. In addition, it is recommended to introduce a quota system for women in the Senate of $30 \%$.

- Make Parliament a woman-friendly environment. Special considerations to be given to values and practices in parliament to ensure that women can apply their opinion and perspectives freely.

- Consider amending the Electoral Law from "One vote" to more than one vote. This will improve women candidates' chance to be elected, given the male dominant and tribal culture of the country.

- Continue legal and regulatory reform to satisfy Jordan's international obligations and enhance the protection of women, specifically in the case of "honor crimes". Furthermore, take appropriate measures to ensure the effective enforcement of the provisions of the laws to protect women.

- Conduct a survey to identify the exact percentage of women in decision making posts in the public and private sectors. Based on the outcomes, the Government should take effective actions to increase the placement of women decision making positions.

- Encourage political parties to adopt voluntary quotas for women, nominate women for parliamentary candidacy, include women as members on their boards and implement campaigns to increase their women's membership.

- Implement national public awareness programs and campaigns to promote women in politics and economics and encourage community dialogues to discuss gender mainstreaming, equity among men and women and the role of women in society and her vital contribution to her community in specific and to the country.

- Conduct more awareness campaigns in various governorates of the country, specifically in rural areas about women's rights under the law. The Target audience should be a mix of men and woman. Encourage open dialogue between them.

\section{References}

Abu Ghazaleh, H. (2009). A report on violence against women (Egypt, Jordan, Syria, Lebanon, Palestine), the National Council for Family Affairs (p. 7, p. 20). Amman, Jordan.

Almadni, M. (2011). American Countries and the African Union's Instruments Used for the Prevention and Combatting Violence against Women. Al Janan Journal (p. 40). Lebanon.

Azzeh, L. (2014). 95\% of rapists go unpunished under disputed Penal Code provision. Retrieved October 14, 2014, from http://jordantimes.com/article/95of-rapists-go-unpunished-under-disputed-penal-code-provision

Bartlett, K. (2000). Feminism and Family Law. Duke University - School of Law. Family Law Quarterly, 33(3), 477, 479, 480.

CEDAW/C/JOR/1. (1997, November). Jordan Initial country report. Convention of the Elimination of all forms of Discrimination against Women (CEDAW). UN.

Center for Reproductive Rights. (2013). The World's Abortion Laws Map 2013 Update. Retrieved from http://reproductiverights.org/sites/crr.civicactions.net/files/documents/AbortionMap_Factsheet_2013.pdf

Cool, J. (2013). Women in Parliament, Library of Parliament Publication No.2011-56. Canada.

Food and Agriculture Organization (FAO), UN. (2010). Percentage of agricultural holding headed by Women. Retrieved from http://www.fao.org/economic/es-policybriefs/multimedia0/female-land-ownership/en/

Gender-based Violence and Child Protection among Syrian refugees in Jordan, with a focus on Early Marriage. (2013, July). Interagency Assessment, Peace and Security UN Women. Amman, Jordan.

Government of Jordan. The Constitution of the Hashemite Kingdom of Jordan. Retrieved October 7, 2014, from 
http://aceproject.org/ero-en/regions/mideast/JO/jordan-constitution-2011

Hamilton, V. (2006). Principles of USA Family Law. Fordham L. Rev., (75), 37.

Inter- Parliamentary Union, Global Database of Quotas for Women. Retrieved from http://www.quotaproject.org/ uid/countryview.cfm?country=113\&http://www.quotaproject.org/uid/countryview.cfm?id=192

International Labor Organization. (1998). More than 120 Nations Provide Paid Maternity Leave. Retrieved from http://www.ilo.org/global/about-the-ilo/newsroom/news/WCMS_008009/lang-en/index.htm

Inter-parliamentary union (IPU). Women in National Parliaments: World Classification. Retrieved October 9, 2014, from http://www.ipu.org/wmn-e/classif.htm

Jordan Ministry of Education. (2014). Statistical Report for the years 2012-2013. Retrieved October 7, 2014, from http://www.moe.gov.jo/Files/report2013/stRe2013.pdf

Jordan Ministry of Health. (2012). Health Indicators. Retrieved October 7, 2014, from http://www.moh.gov.jo/ EN/Pages/mainind.aspx?ind=http\%3a//apps.moh.gov.jo/reports/headermain.jsp?firstjsp=primaryhealthcare menu\&lang_parameter=english

Jordan Olympic Committee. Retrieved October 7, 2014, from http://www.joc.jo/index.php \& http://www.joc.jo/ page.php?id=62-4\&title=Woman \& Sports.

Jordan Statistical Yearbook 2013. Department of statistics of Jordan, Amman, Jordan.

Jordan's Higher Education Annual Report for the year 2012/2013. Ministry of Higher Education \& Scientific Research, Amman, Jordan.

Jordanian Women's Union (JWU). Retrieved October 12, 2014, from http://www.jwu.org.jo/home.aspx?lng=1

May, C. (2014). Report: US 1 of only 7 countries that allow elective abortions after 20 weeks. Retrieved October 14, 2014, from http://dailycaller.com/2014/02/25/report-us-1-of-only-7-countries-that-allow-electiveabortions-after-20-weeks/

Ministry of Health. Retrieved from http://www.moh.gov.jo/EN/Pages/HealthStatisticsandIndicators.aspx

Mohsen, A. (2013, November). Legal Protection of Women under Arab Labor Legislation- Study on reality and aimed future in the light of International and Arab Labor Standards. Workshop on Economic Rights for Arab Women, Manama, Bahrain.

Report No: ACS5158. (2013, July). Economic Participation, Agency and Access to Justice in Jordan. Poverty Reduction and Economic Management Department Middle East and North Africa, World Bank.

Statement on Women Demands presented to the National Committee for Woman Affair (p. 7). (2012).

UNCHR. (1991). Jordan: Jordanian National Charter of 1991. Retrieved October 8, 2014, from http://www.refworld.org/docid/3ae6b53b4.html

UNCHR. (2014). 2014 UNHCR country operations profile - Jordan. Retrieved September 27, 2014, from http://www.unhcr.org/pages/49e486566.html

United Nations Treaty Collection. (2014). Status on Convention on the Elimination of All Forms of Discrimination against Women. Retrieved October 7, 2014, from https://treaties.un.org/Pages/ViewDetails. aspx? src=TREATY\&mtdsg_no=IV-8\&chapter $=4 \&$ lang=en\#EndDec

US Department of Homeland Security, citizenship and immigration. (2014). Green Card for an Immediate Relative of a U.S. Citizen. Retrieved October 13, 2014, from http://www.uscis.gov/green-card/green-cardthrough-family/green-card-immediate-relative-us-citizen

US Department of Labor. (1993). The Family and Medical Leave Act of 1993 Fact Sheet. Retrieved October 13, 2014, from http://www.dol.gov/whd/regs/compliance/whdfs28.pdf

Welchman, L. (2004). Women's Rights and Islamic Family Law (p. 181).

World Economic Forum (WEF). (2013). Global Gender Global Report, Gender Gap Index 2103. Retrieved October 11, 2014, from http://www3.weforum.org/docs/GGGR13/GGGR_CountryProfiles_2013.pdf

\section{Copyrights}

Copyright for this article is retained by the author(s), with first publication rights granted to the journal.

This is an open-access article distributed under the terms and conditions of the Creative Commons Attribution license (http://creativecommons.org/licenses/by/3.0/). 